\title{
GLACIOLOGICAL OBSERVATIONS ON THE
}

\section{"BYRD”, STATION-SOUTH POLE TRAVERSE, 1960-61*}

\section{By Henry H. Brecher}

(Institute of Polar Studies, The Ohio State University, Columbus, Ohio, U.S.A.)

ThIs note presents the results of glaciological observations which were carried out by the author during a traverse from "Byrd" station to Amundsen-Scott South Pole station, Antarctica, in the period December i96o-January ig6i. The route led south-eastward from "Byrd" station to lat. $86^{\circ} \mathrm{S}$., long. $78^{\circ}$ W., a point east of the Thiel Mountains, and thence southward to the South Pole (Fig. I). The journey of 829 miles $(\mathrm{I}, 333 \mathrm{~km}$.) was completed in 34 days.

The main purpose of the traverse was to mark a safe trail for heavy vehicles between the two stations and to transport two heavy "Caterpillar" tractors to Amundsen-Scott station. The glaciological work was limited by the time available during the overnight stops, except that stakes to measure accumulation were set out and occasional surface features were noted while the party was traveling.

Pits were dug to a depth of $2 \mathrm{~m}$. at the 25 sites listed in Table I. Observations of firn temperature, stratigraphy, grain-size and density were made in each pit. All observations were made on one wall of the pit as close together as practical (in a width of about $50 \mathrm{~cm}$.) and were carried out in the order given above.

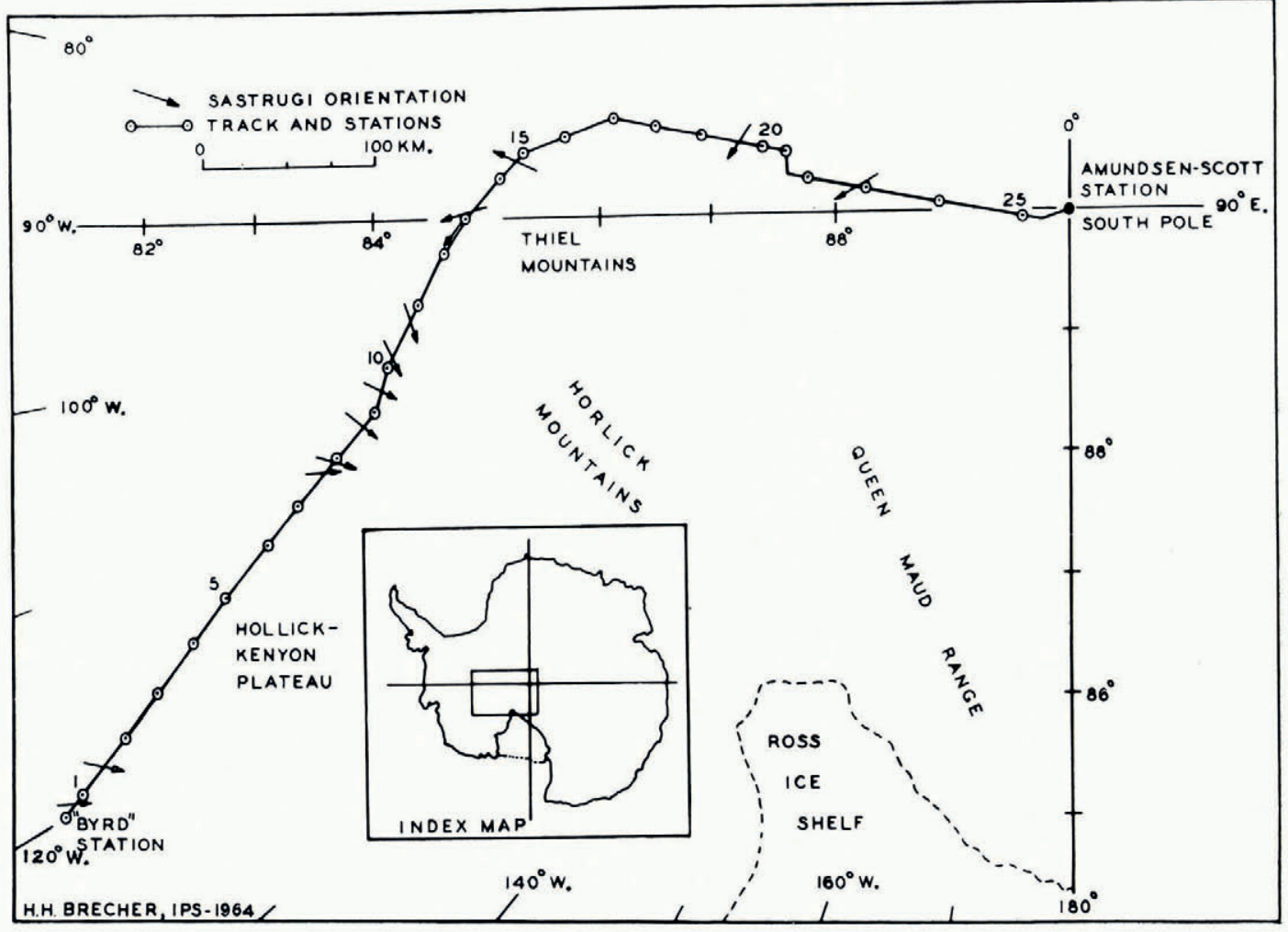

Fig. I. Traverse route showing station locations and prevailing wind directions indicated by sastrugi orientations

* Contribution No. I 3 of the Institute of Polar Studies, The Ohio State University, Columbus, Ohio. 


\begin{tabular}{|c|c|c|c|c|c|c|c|c|}
\hline \multirow[b]{2}{*}{ Station } & \multirow[b]{2}{*}{$\begin{array}{l}\text { Nominal } \\
\text { statute } \\
\text { miles }\end{array}$} & \multirow[b]{2}{*}{$\begin{array}{c}\text { Actual } \\
\text { statute } \\
\text { miles }\end{array}$} & \multicolumn{2}{|c|}{ Position } & \multirow{2}{*}{$\begin{array}{c}\text { Elevation } \\
\mathrm{m} .\end{array}$} & \multirow{2}{*}{$\begin{array}{c}\text { Number } \\
\text { of years } \\
\text { for } \\
\text { accumulation } \\
\text { determination }\end{array}$} & \multirow[b]{2}{*}{$\begin{array}{c}\text { Mean } \\
\text { annual } \\
\text { accumulation } \\
\mathrm{g} . / \mathrm{cm} .^{2}\end{array}$} & \multirow{2}{*}{$\begin{array}{c}\text { Approximate } \\
\text { mean } \\
\text { annual } \\
\text { air temperature } \\
-{ }^{\circ} \mathrm{C} \text {. }\end{array}$} \\
\hline & & & Lat. S. & Long. $W$. & & & & \\
\hline "Byrd" & 0 & o & $79^{\circ} 59^{\prime} 20^{\prime \prime}$ & $120^{\circ} \mathrm{OI}^{\prime}$ & I 525 & 4 & $12 \cdot 4$ & $28 \cdot 4$ \\
\hline I & 17 & 17 & $80^{\circ} 13^{\prime}$ & $119^{\circ} 30^{\prime}$ & 1426 & 5 & $12 \cdot 7$ & $27 \cdot 9$ \\
\hline 2 & 57 & 58 & $80^{\circ} 47^{\prime}$ & $118^{\circ} \mathrm{o} 6^{\prime}$ & I 494 & 6 & $1 \mathrm{I} \cdot 3(12 \cdot 0)$ & $27 \cdot 7$ \\
\hline 3 & 90 & 91 & $8 \mathrm{I}^{\circ} \mathrm{I}^{\prime}$ & I $16^{\circ} 48^{\prime}$ & 1417 & 6 & $10.6(11 \cdot 1)$ & $26 \cdot 2$ \\
\hline 4 & 125 & 126 & $81^{\circ} 37^{\prime}$ & $1152^{\circ}$ & 1394 & 7 & $10 \cdot 3(10 \cdot 4)$ & $26 \cdot 4$ \\
\hline 5 & 160 & I 62 & $82^{\circ} \mathrm{O} 5^{\prime}$ & I $13^{\circ} 43^{\prime}$ & 1368 & 7 & $10 \cdot 3(10 \cdot 6)$ & $27 \cdot 3$ \\
\hline 6 & I97 & 200 & $82^{\circ} 34^{\prime}$ & I I I 4 I $^{\prime}$ & $145^{8}$ & 7 & $10.7(10.8)$ & $27 \cdot 4$ \\
\hline 7 & 225 & 229 & $82^{\circ} 56^{\prime}$ & I $10^{\circ} 6^{\prime}$ & 1607 & 5 & $12 \cdot 0$ & $27 \cdot 9$ \\
\hline 8 & 261 & $26 \hat{6}$ & $83^{\circ} 23^{\prime}$ & $107^{\circ} 40^{\prime}$ & 1761 & 4 & I $3 \cdot 4$ & $30 \cdot 3$ \\
\hline 9 & 294 & 300 & $83^{\circ} 47^{\prime}$ & $105^{\circ} 15^{\prime}$ & I 808 & 4 & $14 \cdot 3$ & $33 \cdot 7$ \\
\hline IO & 324 & 327 & $83^{\circ} 59^{\prime}$ & $102^{\circ} 12^{\prime}$ & I973 & 4 & $14 \cdot 4$ & $35 \cdot 8$ \\
\hline II & 357 & 369 & $84^{\circ} 2 I^{\prime}$ & $97^{\circ} 25^{\prime}$ & 2064 & 4 & $13 \cdot 8$ & $3^{8} \cdot 5$ \\
\hline 12 & $3^{8} 7$ & 404 & $84^{\circ} 3^{8^{\prime}}$ & $93^{\circ} \mathrm{o} 6^{\prime}$ & 2005 & 5 & $13 \cdot 7(14 \cdot 8)$ & $3^{8 \cdot 1}$ \\
\hline 13 & $4^{16}$ & 429 & $84^{\circ} 5^{I^{\prime}}$ & $90^{\circ} \mathrm{OO}^{\prime}$ & 1760 & 5 & $12 \cdot 6(13 \cdot 7)$ & $35 \cdot 5$ \\
\hline 14 & 446 & 459 & $85^{\circ} \mathrm{O} 4^{\prime}$ & $86^{\circ} 14^{\prime}$ & I 560 & 5 & $12 \cdot 3(14 \cdot 5)$ & $34 \cdot 9$ \\
\hline 15 & 466 & $4^{81}$ & $85^{\circ} 16^{\prime}$ & $83^{\circ} 20^{\prime}$ & I 397 & 5 & $12 \cdot 5(12 \cdot 9)$ & $33 \cdot 3$ \\
\hline I 6 & 492 & $5^{\circ 08}$ & $85^{\circ} 37^{\prime}$ & $81^{\circ} 07^{\prime}$ & 1488 & 5 & I $2 \cdot 8(14 \cdot 0)$ & $35 \cdot 2$ \\
\hline 17 & 522 & $53^{8}$ & $86^{\circ} \mathrm{oo}^{\prime}$ & $78^{\circ} 10^{\prime}$ & I6I3 & 5 & I $2.1(13 \cdot 8)$ & $3^{6 \cdot 9}$ \\
\hline I 8 & $54^{8}$ & $5^{65}$ & $86^{\circ} 23^{\prime}$ & $78 \cdot 2^{\circ}$ & 1806 & 5 & I I $\cdot 8($ I $3 \cdot 3)$ & $37 \cdot 1$ \\
\hline I9 & 575 & 593 & $86^{\circ} 4^{8^{\prime}}$ & $78 \cdot \mathrm{I}^{\circ}$ & I 994 & 7 & $10.7(10.8)$ & $34 \cdot 8$ \\
\hline 20 & 6 Io & 629 & $87^{\circ} 19^{\prime}$ & $78 \cdot 0^{\circ}$ & $233^{\circ}$ & 6 & $9 \cdot 6(9 \cdot 8)$ & $39 \cdot 5$ \\
\hline 21 & 624 & 645 & $87^{\circ} 32^{\prime}$ & $78 \cdot 0^{\circ}$ & 2449 & 6 & $8 \cdot 8(9 \cdot 4)$ & $39 \cdot 9$ \\
\hline 22 & 647 & 672 & $87^{\circ} 4^{\prime}$ & $82 \cdot 8^{\circ}$ & 2533 & 6 & $10.0(10.4)$ & $45 \cdot 0$ \\
\hline 23 & 680 & 705 & $88^{\circ} 14^{\prime}$ & $83 \cdot 6^{\circ}$ & 2689 & 6 & $9 \cdot 3(10 \cdot 1)$ & $46 \cdot 7$ \\
\hline 24 & 725 & $75^{1}$ & $88^{\circ} 54^{\prime}$ & $85 \cdot 8^{\circ}$ & 2703 & 6 & $10 \cdot 3(11 \cdot 7)$ & $5^{0} \cdot 3$ \\
\hline 25 & 775 & 801 & $89^{\circ} 3^{\prime}$ & $97 \cdot 0^{\circ}$ & 28 I 4 & 6 & $9 \cdot 6$ & $5^{I \cdot 2}$ \\
\hline
\end{tabular}

Firn temperatures were measured at $10 \mathrm{~cm}$. vertical intervals, using Weston dial thermometers which had been calibrated at $-23 \cdot \mathrm{I}^{\circ} \mathrm{C}$., the temperature in the "Byrd" station deep pit room. To eliminate possible errors because of different positions of the pointer, all thermometer dials were orientated in an "upright" position and the dial was tapped gently before each reading.

Because of the author's lack of previous glaciological experience, it seemed desirable at the time to make the observations as free as possible from personal interpretations. For this reason both stratigraphy and grain-size were recorded photographically. The firn stratigraphy record consists of pit wall photographs without supplementary descriptions. Unfortunately, because of mechanical difficulties, the pit wall could be illuminated properly only at stations $\mathrm{I}$ through 5 and ro through I3. Most of the photographs, therefore, lack the necessary contrast to distinguish layers clearly.

Grain-size data were obtained by photographing snow grains spread on a millimeter grid. As the expense of making prints of the 700 exposures thus obtained did not seem justified, an attempt was made to determine grain-size by looking at the negatives on a microfilm viewer. However, this procedure was quite unsatisfactory. Since it is doubtful whether reliable grainsize determinations can be made from these photographic (i.e. two-dimensional) data, they remain unevaluated.

Densities were measured by the usual method of weighing $500 \mathrm{~cm} .{ }^{3}$ firn samples obtained with sampling tubes pushed into the pit wall horizontally at $5 \mathrm{~cm}$. vertical intervals. Some tubes were slightly distorted during sampling in each pit but severe deformation was infrequent. When a tube was deformed to such an extent that its volume had been appreciably affected, the sample was either repeated or disregarded. A spring balance, equipped with a rotatable scale for zero setting and graduated in $2 \mathrm{~g}$. intervals, was used for weighing the samples. Repeatability of readings was good, and it is believed that the weights are accurate to $\pm \mathrm{I} g$., so that the relative densities should be accurate to $\pm 0.02 \mathrm{~g} . / \mathrm{cm} .{ }^{3}$. 


$$
\text { “BYRD”, STATION-SOUTH POLE TRAVERSE, I 960-6I }
$$

Table I and Figure 2 summarize the mean annual accumulation and approximate mean annual air temperature values obtained from the pit observations. Station positions are derived largely from information furnished by the traverse navigator, CWO George W. Fowler, and elevations were computed by Mr. Forrest L. Dowling, who carried out geophysical observations on this traverse.

The accumulation values are based entirely on interpretations of the cyclic fluctuations of density with depth, which are quite pronounced and could be followed reasonably well from pit to pit. Each segment between breaks in the density profile was considered to represent one year's accumulation and was reduced to its water equivalent by using the corresponding density for each $5 \mathrm{~cm}$. portion. The top and bottom years were not considered in the computation of mean accumulation to eliminate the possibility of including incomplete years. The resulting mean accumulation figures were obtained from layers believed to represent from four complete years in some pits to seven in others. Where two figures are given they represent two possible interpretations, with the less likely one in parentheses in the table and as a dashed line on the graph (Fig. 2). The small accumulation on the Hollick-Kenyon Plateau north of the Horlick Mountains, the maximum in the area east of the mountains, and the gradual decrease of accumulation southward on the polar plateau are possible evidence of an orographic effect.

The approximate mean annual air temperatures given are values calculated by $\mathrm{C}$. Bull (personal communication). They represent $10 \mathrm{~m}$. firn temperatures obtained by an extrapolation (based on the differences between 2 and io m. temperatures at "Byrd" and

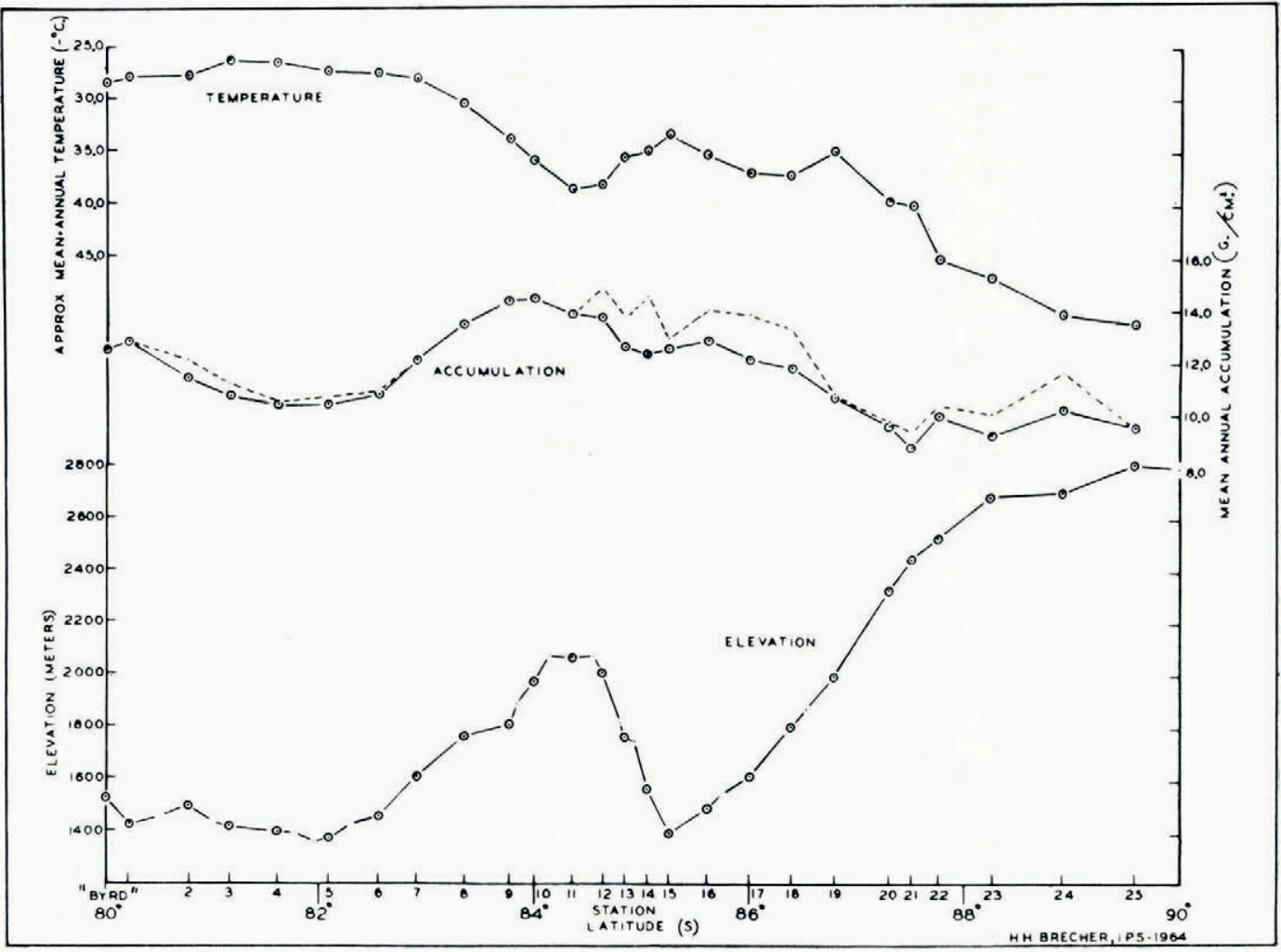

Fig. 2. Approximate mean annual air temperatures, mean annual accumulations and elevations of traverse stations 
Amundsen-Scott stations) of the average of the temperatures measured in the pits at Igo and $200 \mathrm{~cm}$. Because of the assumptions in the extrapolation and the low precision of the dial thermometer readings, these estimates of mean annual temperature may be considerably in error (up to $2^{\circ}$ C.). . Nevertheless, these temperatures are strongly dependent on elevation and latitude, as expected.

One hundred and fifty-seven snow accumulation stakes $(6 \mathrm{ft} .(\mathrm{I} \cdot 8 \mathrm{~m}$.) lengths of bamboo with metal number tags) were set out at 5 mile $(8 \mathrm{~km}$.) intervals beginning at mile $5(8 \mathrm{~km}$.) and ending at mile 795 (I,279 km.). The stakes are numbered consecutively from IOI (at mile $5(8 \mathrm{~km}$. $)$ ) to 257 (at mile $795(\mathrm{r}, 279 \mathrm{~km}$.)). There are no stakes at miles 625 ( $\mathrm{r}, 005 \mathrm{~km}$.) and 630 ( $1,013 \mathrm{~km}$.) which are in a crevasse area. The stakes were pushed in deep enough to stand securely and the length protruding above the surface was measured to the nearest centimeter. Due to the travel arrangements, this work could be done most conveniently from the navigation "Weasel". CWO Fowler set out the stakes and the "Weasel"'driver, PO Shirley F. Mahan, recorded the measurements. At 14 locations $20 \times 20 \mathrm{~cm}$. plywood boards were placed adjacent to and in the "poleward" direction from the stakes to mark the existing surface.

The 27 stakes from the South Pole to approximately lat. $88^{\circ} \mathrm{S}$. were re-measured during the South Pole traverse in $1962-63$, two years later. There is considerable scatter in the accumulation values calculated from these measurements and surface densities obtained in the South Pole traverse pit studies (Fig. 3). Part of this is due to the local topographic setting of the individual stakes. One stake was surrounded by a high localized drift and has been disregarded. There appears to be a slight decrease in accumulation toward the South Pole. The accumulations determined from the pit studies have been added to Figure 3 for comparison. The mean annual accumulation from these measurements is $7.4 \mathrm{~g} . / \mathrm{cm} .{ }^{2}$, which is in good agreement with values for the South Pole, e.g. those given by Giovinetto (196o, p. 5-9o).

A few scattered sastrugi orientations were determined by estimating their directions relative to the travel track. Unusually rough or smooth stretches of surface were also noted.

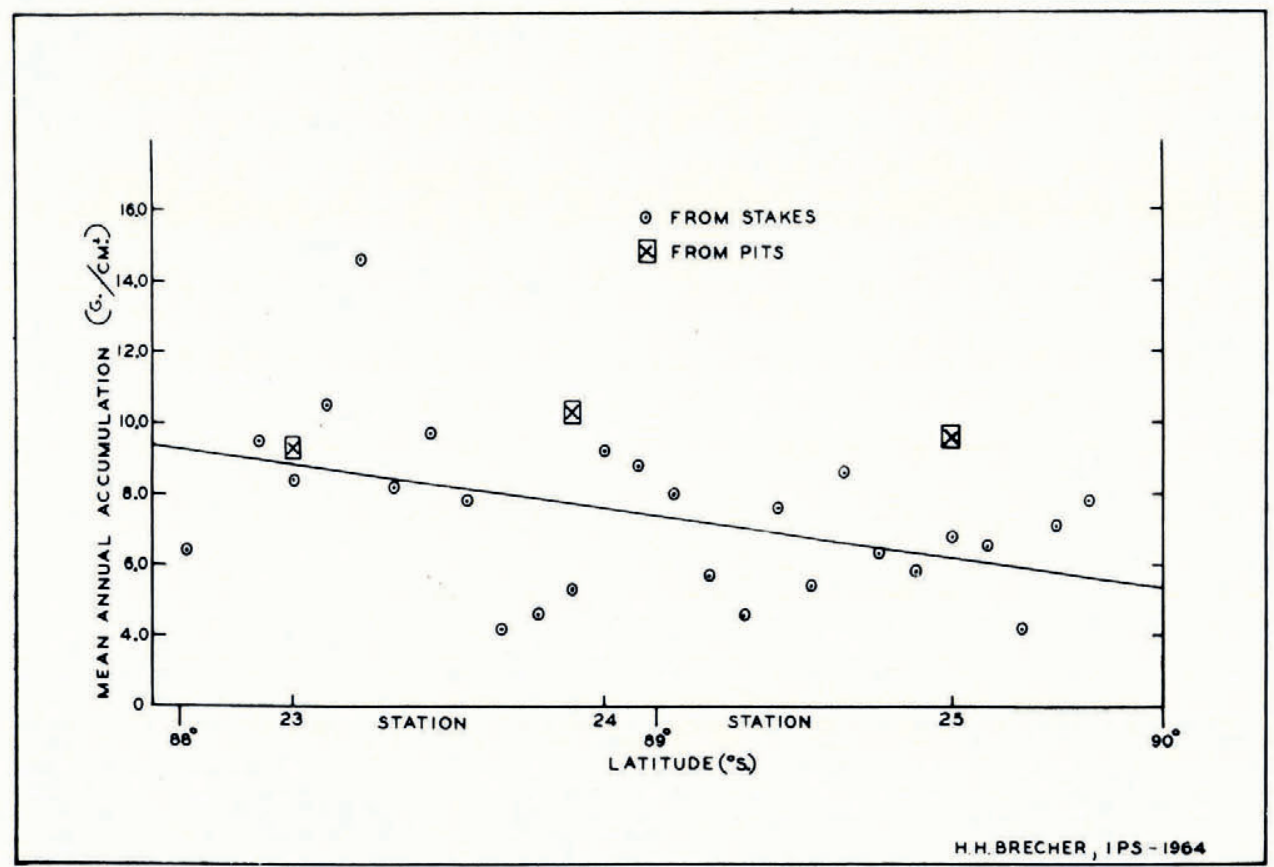

Fig. 3. Mean annual accumulations from measurements in $196 \mathrm{I}$ and 1963 of 27 stakes between lat. $88^{\circ} \mathrm{S}$. and the South Pole 


$$
\text { “'BYRD”, STATION-SOUTH POLE TRAVERSE, I 960-6I }
$$

The observations are summarized in Table II and sastrugi, i.e. prevailing wind, directions are indicated by arrows in Figure $\mathrm{I}$.

\begin{tabular}{|c|c|c|}
\hline Mile & $\begin{array}{c}\text { Estimated } \\
\text { direction } \\
\text { (from true north) }\end{array}$ & Remarks \\
\hline $0-17$ & 025 & \\
\hline 37 & 040 & $\begin{array}{l}\text { Height increasing, disposed in patches } 30 \text { to } 100 \mathrm{yd} \text {. ( } 27 \text { to } 91 \mathrm{~m} \text {.) apart, } \\
\text { patches approximately } 10 \mathrm{yd} \text {. }(9 \mathrm{~m} \text {.) square, height } 6 \text { to } 10 \mathrm{in} \text {. ( } 15 \text { to } 25 \mathrm{~cm} \text {.), } \\
\text { occasionally higher. }\end{array}$ \\
\hline I IO & - & $\begin{array}{l}\text { Noticeably higher snow drifts ( } 1 \mathrm{ft} .(0.3 \mathrm{~m} .)) \text { and soft } \mathrm{I} \mathrm{ft} .(\mathrm{o} .3 \mathrm{~m} .) \text { sastrugi, } \\
\text { well-scattered. }\end{array}$ \\
\hline 225 & - & $\begin{array}{l}\text { Scattered high sastrugi or drifts (approximately } 2 \mathrm{ft} \text {. (o.6 m.) high, io to } \\
30 \mathrm{ft} \text {. ( } 3 \text { to } 9 \mathrm{~m} \text {.) long), not clearly visible under cover of new snow. }\end{array}$ \\
\hline 246 & - & Surface very smooth. \\
\hline 250 & OI5 & Secondary direction 105. \\
\hline 258 & 035 & \\
\hline 283 & 055 & Surface very rough, sastrugi $\mathrm{I}$ in. $(2.5 \mathrm{~cm}$.) to $2 \mathrm{ft}$. $(0.6 \mathrm{~m}$.) high. \\
\hline 3 IO & 040 & Surface fairly rough. \\
\hline $324-337$ & $065-085$ & \\
\hline $337-357$ & 080 & \\
\hline 409 & 130 & \\
\hline 420 & 165 & \\
\hline $\begin{array}{l}459 \\
514\end{array}$ & 200 & $\begin{array}{l}\text { Surface very rough and hard }(63 \mathrm{~cm} \text {. sastrugi height measured). } \\
\text { Surface exceptionally smooth and soft. }\end{array}$ \\
\hline 597 & 110 & $\begin{array}{l}\text { Surface very rough and hard, scattered narrow sastrugi up to } 2 \mathrm{ft} \text {. }(0.6 \mathrm{~m} \text {.) } \\
\text { high. }\end{array}$ \\
\hline $630-64 \mathrm{I}$ & - & Surface extremely rough, large and extensive drifts and sastrugi. \\
\hline 675 & 140 & Sastrugi direction variable, surface very soft and smooth. \\
\hline
\end{tabular}

\section{Acknowledgements}

I want to express my thanks to the following for their contributions to this project: Arctic Institute of North America, my employer at the time of the traverse, for allowing me to participate; Lt. Col. Antero Havola, leader of the traverse, for inviting me to go along; Dr. Richard P. Goldthwait for encouragement in the form of supplies and training in techniques; my traverse companions, particularly CWO Fowler and PO Mahan, for their assistance; and Dr. Colin Bull for his interest in, and suggestions for, this presentation of the results.

MS. received I I February 1964

\section{REFERENCE}

Giovinetto, M. B. 1960. South Pole glaciological data 1958. Ohio State University Research Foundation. Report 825-2-Part IV. 